\title{
OPTIMASI PEMOTONGAN BAHAN KAYU UNTUK PRODUK MEJA DI INDUSTRI MEUBEL CIPTA KARYA MANDIRI, ADIARSA BARAT - KARAWANG
}

\author{
Ade Suhara, ST.,MM.
}

Fakultas Teknologi dan Ilmu Komputer, Universitas Buana Perjuangan Karawang, 2016

\begin{abstract}
ABSTRAK
Industri meubel menggunakan batang kayu yang masih berbentuk batangan (lonjoran) untuk membuat produknya. Kayu-kayu batangan ini kemudian harus dipotong-potong sesuai dengan ukuran yang dibutuhkan oleh tiap komponen penyusun produk. Hal yang menjadi masalah adalah bahwa pihak perusahaan terkesan asalasalan dalam memotong kayu lonjoran tadi tanpa memperhitungkan sisa-sisa pemotongan yang mungkin terjadi.

Penelitian ini menawarkan cara pemotongan yang sebaiknya dilakukan terhadap kayu batangan tersebut agar diperoleh potongan-potongan yang memberikan sisa pemotongan yang sekecil atau seminimal mungkin. Teknik yang digunakan untuk memecahkan masalah ini adalah dengan menggunakan programa linier, dimana pemecahan masalahnya menggunakan metode simpleks dengan teknik dua fase.
\end{abstract}

Kata Kunci : Programa Linier, Teknik Simpleks Dua Fase, Sisa Pemotongan

\section{A. PENDAHULUAN}

Sejak krisis ekonomi melanda Indonesia sejak pertengahan tahun 1997, begitu banyak industri besar yang tumbang dan bahkan mengalami kebangkrutan karena tidak mampu lagi menanggung beban hutang yang makin membesar sebagai akibat adanya perubahan nilai mata uang (kurs) yang sangat drastis. Hal tersebut mengakibatkan terjadinya PHK (pemutusan hubungan kerja) besar-besaran, sehingga tingkat pengangguran di Indonesia makin tinggi. Di tengah situasi seperti ini, industri / usaha kecil tumbuh dengan suburnya bagaikan cendawan di musim hujan, dan terbukti, hanya industri-industri kecil inilah yang mampu bertahan di tengah hantaman krisis yang melanda bangsa Indonesia. Dengan demikian, dapat dikatakan juga bahwa sektor industri kecil ini merupakan sektor yang potensial untuk menampung para pencari kerja yang makin banyak dari waktu ke waktu.

Apabila kita perhatikan, banyak sekali jenis industri dan usaha kecil yang tumbuh di sekitar kita, misalnya warung (warung makan, warung kelontong, dan sebagainya), persewaan alat elektronik (rental komputer, rental CD, rental playstation, dan lain-lain), bengkel, dan industri meubel rumahan. Akan tetapi, tumbuhnya 
berbagai industri kecil ini tidak dibarengi dengan bekal pengetahuan manajemen yang baik dari para pengelolanya sehingga bisa saja menimbulkan kerugian yang mungkin tidak disadari oleh mereka. Hal ini adalah salah satu kelemahan yang dimiliki oleh industri kecil tersebut. Salah satu contohnya adalah di industri meubel Cipta Karya Mandiri, Adiarsa Barat - Karawang yang akan menjadi fokus dalam penelitian ini.

Bahan utama yang digunakan dalam sebuah industri meubel adalah kayu, apapun jenisnya, baik kayu meranti, borneo, jati, maupun yang lain. Dalam proses produksinya, untuk membuat suatu produk tertentu, misalnya kusen, meja, dan kursi, kayu yang pada awalnya berbentuk lonjoran dengan panjang sekitar 2 atau 4 meter harus dipotong-potong sesuai dengan ukuran komponen yang akan dibentuk. Misalnya untuk komponen kaki dari rangka kursi dengan ukuran $45 \mathrm{~cm}$, maka kayu lonjoran dengan panjang 2meter tersebut harus dipotong-potong menjadi ukuran $45 \mathrm{~cm}$ sebanyak kebutuhan, dan akan memberikan sisa pemotongan sepanjang $20 \mathrm{~cm}$. Seringkali cara pemotongan ini tidak diperhitungkan sehingga menimbulkan sisa-sisa pemotongan yang cukup banyak yang tidak dapat digunakan lagi dan harus dibuang sebagai sampah/limbah. Selain itu, kebutuhan total kayu belum bisa diketahui sejak awal, sehingga perusahaan tidak bisa memperkirakan berapa batang kayu lonjoran yang harus dibeli ke pihak penyedia material (supplier).

Berdasarkan uraian di atas, maka hal yang menjadi perumusan masalah dan akan dibahas dalam penelitian ini adalah:

1. Bagaimana cara pemotongan bahan yang sebaiknya dilakukan agar sisa-sisa pemotongan yang terjadi adalah seminimal mungkin?

2. Berapa batang kayu lonjoran yang harus disediakan untuk memenuhi target produksi sesuai permintaan konsumen?

\section{B. LANDASAN TEORI}

\section{Pengertian Umum Programa Linier}

Programa linier atau Linear Programming (LP) adalah suatu cara untuk menyelesaikan persoalan pengalokasian sumber-sumber yang terbatas di antara beberapa aktivitas yang bersaing, dengan cara yang terbaik yang mungkin dilakukan. Persoalan pengalokasian ini akan muncul manakala seseorang harus memilih tingkat aktivitas-aktivitas tertentu yang bersaing dalam hal penggunaan sumber daya langka yang dibutuhkan untuk melaksanakan aktivitas-aktivitas 
tersebut. Misalnya persoalan pengalokasian fasilitas produksi, pengalokasian sumber daya nasional untuk kebutuhan domestik, dan pemilihan pola pengiriman (shipping). Satu hal yang menjadi ciri situasi di atas ialah adanya keharusan untuk mengalokasikan sumber terhadap aktivitas.

Programa linier (LP) adalah perencanaan aktivitas-aktivitas untuk memperoleh suatu hasil yang optimum, yaitu suatu hasil yang mencapai tujuan terbaik di antara seluruh alternatif yang fisibel.

Karakteristik-karakteristik yang biasa digunakan dalam persoalan programa linier dalam membangun model dari formulasi sebuah persoalan yaitu :

a. Variabel keputusan, adalah variabel yang menguraikan secara lengkap keputusan-keputusan yang akan dibuat.

b. Fungsi tujuan, merupakan fungsi dari variabel keputusan yang akan dimaksimumkan (untuk pendapatan atau keuntungan) atau diminimumkan (untuk ongkos).

c. Pembatas, merupakan kendala yang dihadapi sehingga kita tidak bisa menentukan harga-harga variabel keputusan secara sembarang.

Koefisien dari variabel keputusan pada pembatas disebut koefisien teknologis, sedangkan bilangan yang ada di sisi kanan setiap pembatas disebut ruas kanan pembatas.

d. Pembatas tanda, adalah pembatas yang menjelaskan apakah variabel keputusannya diasumsikan hanya berharga nonnegatif atau variabel tersebut boleh berharga positif, boleh juga negatif (tidak terbatas dalam tanda).

\section{Teknik Pemecahan Model Programa Linier}

Ada dua cara yang bisa digunakan untuk menyelesaikan persoalan-persoalan programa linier ini, yaitu dengan cara grafis dan dengan metode simpleks.

Cara grafis dapat kita pergunakan apabila persoalan programa linier yang akan diselesaikan itu hanya mempunyai dua buah variabel. Walaupun demikian, cara ini telah memberikan satu petunjuk penting bahwa untuk memecahkan persoalan-persoalan programa linier, kita hanya perlu memperhatikan titik ekstrem (titik terjauh) pada ruang solusi atau daerah fisibel. Petunjuk ini telah menjadi kunci dalam mengembangkan metode simpleks. 
Metode simpleks merupakan teknik yang paling berhasil dikembangkan untuk memecahkan persoalan programa linier yang mempunyai jumlah variabel keputusan dan pembatas yang besar. Algoritma simpleks ini diterangkan dengan menggunakan logika secara aljabar matriks, sedemikian sehingga operasi perhitungan dapat dibuat lebih efisien.

\section{Menyelesaikan Persoalan Programa Linier dengan Pembatas Bertanda $\geq$ dan atau $=$}

Dalam pembicaraan mengenai metode simpleks, kita dapat menggunakan variabel slack sebagai solusi basis awal, sedemikian sehingga masing-masing merupakan ruas kanan yang berharga positif pada masing-masing persamaan.

Sekarang perhatikan untuk kasus yang persamaan pembatasnya tidak lagi bertanda $(\leq)$, tetapi bertanda $(=)$ atau $(\geq)$. Untuk kasus yang persamaan pembatasnya bertanda $(=)$, daerah fisibelnya hanya berupa segmen garis sehingga kita tidak dapat memperoleh solusi fisibel basis awal karena tidak ada variabel slack yang dapat digunakan sebagai variabel basis awalnya. Sebagai contoh, bila persamaan pembatas dari suatu persoalan diubah dari $3 \mathrm{x}_{1}+2 \mathrm{x}_{2} \leq 18$ menjadi $3 \mathrm{x}_{1}+$ $2 \times 2=18$, maka daerah fisibelnya hanya berupa garis yang menghubungkan titik ( 2 , 6) dengan $(4,3)$. Demikian juga untuk kasus dengan persamaan pembatas bertanda $(\searrow)$, kita tidak akan memiliki solusi fisibel basis awal karena ruas kanannya berharga negatif. Contoh: $3 \mathrm{x}_{1}+2 \mathrm{x}_{2} \geq 18$, adalah sama dengan $-3 \mathrm{x}_{1}-2 \mathrm{x}_{2} \leq-18$. Dengan menambahkan variabel slack menjadi $-3 \mathrm{x}_{1}-2 \mathrm{x}_{2}+\mathrm{S}_{3} \leq-18, \mathrm{~S}_{3}$ tidak bisa menjadi variabel basis awal karena harganya negatif.

Untuk menyelesaikan kedua jenis kasus tersebut, kita memerlukan adanya variabel dummy (variabel palsu) yang disebut variabel artifisial, sehingga variabel basis awal bisa tetap ada. Sebagai ilustrasi, kita lihat contoh berikut:

\section{Contoh 1:}

Maksimumkan: $\mathrm{z}=3 \mathrm{x} 1+5 \mathrm{x} 2$

Berdasarkan pembatas:

$\mathrm{X} 1$

$2 \times 2 \leq$

$3 \mathrm{x} 1+$

$$
\leq 4
$$

12

$2 \times 2=$ 18

$$
\mathrm{X} 1, \mathrm{X} 2 \geq 0
$$


Bentuk di atas kita ubah menjadi:

$$
\begin{aligned}
\mathrm{z}-3 \mathrm{x} 1-5 \mathrm{x} 2 & =0 \\
\mathrm{x}_{1}+\mathrm{S}_{1} & =4 \\
2 \mathrm{x}_{2}+\mathrm{S}_{2} & =12 \\
3 \mathrm{x}_{1}+2 \mathrm{x}_{2}+\mathrm{R}_{3} & =18 \\
\mathrm{x} 1, \mathrm{x}_{2}, \mathrm{~S}_{1}, \mathrm{~S}_{2}, \mathrm{R}_{3} \geq 0 &
\end{aligned}
$$

Pengaruh variabel artifisial (R) ini adalah untuk memperluas daerah fisibel.

\section{Contoh 2:}

Maksimumkan: $\mathrm{z}=3 \mathrm{x} 1+5 \mathrm{x} 2$

Berdasarkan pembatas:

$\mathrm{X} 1$

$2 \times 2 \geq$

$3 \mathrm{x} 1+$

$$
\geq 4
$$

12

$$
2 \times 2=18
$$

$$
\mathrm{X} 1, \mathrm{X} 2 \geq 0
$$

Bentuk di atas kita ubah menjadi:

$$
\begin{aligned}
\mathrm{z}-3 \mathrm{x}_{1}-5 \mathrm{x}_{2} & =0 \\
\mathrm{x}_{1}-\mathrm{S}_{1}+\mathrm{R}_{1} & =4 \\
2 \mathrm{x}_{2}+\mathrm{S}_{2}+\mathrm{R}_{2} & =12 \\
+\mathrm{R}_{3}= & 18 \\
3 \mathrm{x}_{1}+2 \mathrm{x}_{2} & \\
\mathrm{x}_{1}, \mathrm{x}_{2}, \mathrm{~S}_{1}, \mathrm{~S}_{2}, \mathrm{R}_{1}, \mathrm{R}_{2}, \mathrm{R}_{3}>0 &
\end{aligned}
$$

Pada akhirnya, iterasi-iterasi metode simpleks akan secara otomatis menjadikan variabel artifisial ini tidak muncul lagi (berharga nol), yaitu apabila persoalan semula telah terselesaikan. Dengan kata lain, kita gunakan variabel artifisial ini hanya untuk memulai solusi, dan harus menghilangkannya (menjadikannya berharga nol) pada akhir solusi. Jika tidak demikian, solusi yang diperoleh akan tidak fisibel. Untuk itu, maka harus diberikan penalty M (M adalah bilangan positif yang sangat besar) pada setiap variabel artifisial dalam fungsi tujuannya. Contoh: dari contoh 2 di atas, fungsi tujuannya menjadi:

$$
\begin{gathered}
\mathrm{z}=3 \mathrm{x}_{1}+5 \mathrm{x}_{2}-\mathrm{MR}_{1}-\mathrm{MR}_{2}-\mathrm{MR}_{3} \\
\text { atau } \quad \mathrm{z}-3 \mathrm{x}_{1}-5 \mathrm{x}_{2}+\mathrm{MR}_{1}+\mathrm{MR}_{2}+\mathrm{MR}_{3}=0
\end{gathered}
$$

Perhatikan bahwa penalty di atas bertanda (-) karena fungsi tujuannya berupa maksimasi. Jika fungsi tujuannya berupa minimasi, maka penalty bertanda (+). 
Ada dua teknik penyelesaian untuk kasus dengan variabel artifisial ini, yaitu (1) teknik M dan (2) teknik dua fase. Kedua teknik ini saling berkaitan erat.

\section{a. Teknik M (metode penalty)}

Perhatikan persoalan di bawah ini:

Maksimumkan: $\mathrm{z}=3 \mathrm{x} 1+5 \mathrm{x} 2$

Berdasarkan pembatas:

$$
\begin{aligned}
\mathrm{x}_{1} & \leq 4 \\
2 \mathrm{x}_{2} & \leq 12 \\
3 \mathrm{x}_{1}+2 \mathrm{x}_{2} & =18 \\
\mathrm{x} 1, \mathrm{x}_{2} \geq 0 &
\end{aligned}
$$

Karena pembatas ketiga bartanda (=), maka untuk mendapatkan solusi basis awalnya kita harus menambahkan variabel artifisial sehingga diperoleh bentuk:

Maksimumkan: $\mathrm{z}=3 \mathrm{x}_{1}+5 \mathrm{x}_{2}+\mathrm{OS}_{1}+\mathrm{OS}_{2}-\mathrm{MR}_{3}$

Berdasarkan pembatas

$$
\begin{aligned}
& \begin{array}{lll}
\mathrm{X}_{1}+\mathrm{S}_{1} & =4
\end{array} \\
& 2 \mathrm{x} 2_{2}+\mathrm{S}_{2} \quad=12 \\
& 3 \mathrm{x}_{1}+2 \mathrm{x}_{2}+\mathrm{R}_{3}=18 \\
& \mathrm{x} 1, \mathrm{x} 2, \mathrm{~S}_{1}, \mathrm{~S}_{2}, \mathrm{R}_{3} \geq 0
\end{aligned}
$$

Untuk memasukkan model di atas ke dalam bentuk tabel, maka terlebih dahulu disubstitusikan $\mathrm{R} 3$ dengan cara:

$$
\mathrm{R}_{3}=18-3 \mathrm{x}_{1}-2 \mathrm{x}_{2}
$$

Kemudian masukkan ke dalam persamaan z sebagai berikut:

$$
\mathrm{z}=3 \mathrm{x}_{1}+5 \mathrm{x}_{2}+\mathrm{OS}_{1}+\mathrm{OS}_{2}-\mathrm{M}\left(18-3 \mathrm{x}_{1}-2 \mathrm{x}_{2}\right)
$$

atau:

$$
\begin{aligned}
& \mathrm{z}=(3 \mathrm{M}+3) \mathrm{x} 1+(2 \mathrm{M}-5) \mathrm{x}_{2}+\mathrm{OS}_{1}+\mathrm{OS}_{2}-18 \mathrm{M} \\
& \mathrm{z}-(3 \mathrm{M}+3) \mathrm{x}_{1}-(2 \mathrm{M}+5) \mathrm{x}_{2}-\mathrm{OS}_{1}-\mathrm{OS}_{2}=-18 \mathrm{M}
\end{aligned}
$$

Hal ini dilakukan dengan maksud agar dalam pembuatan tabel simpleks awalnya, R3 sudah secara otomatis "dipaksa" berharga nol. Selanjutnya selesaikan persoalan di atas dengan cara yang sama. Lihat Tabel 1. 
Tabel 1. Tabel simpleks penyelesaian persoalan dengan pembatas ketiga bertanda (=)

\begin{tabular}{|c|c|c|c|c|c|c|c|c|}
\hline Iterasi & Basis & $\mathrm{z}$ & $\mathrm{X} 1$ & $\mathrm{X} 2$ & $\mathrm{~S}_{1}$ & $\mathrm{~S}_{2}$ & $\mathrm{R}_{3}$ & Solusi \\
\hline \multirow{4}{*}{0} & $\bar{Z}$ & 1 & $(-3 \mathrm{M}-3)$ & $(-2 M-5)$ & 0 & 0 & 0 & $-18 \mathrm{M}$ \\
\hline & $\mathrm{S}_{1}$ & 0 & 1 & 0 & 1 & 0 & 0 & 4 \\
\hline & $\mathrm{S}_{2}$ & 0 & 0 & 2 & 0 & 1 & 0 & 12 \\
\hline & $\mathrm{R}_{3}$ & 0 & 3 & 2 & 0 & 0 & 1 & 18 \\
\hline \multirow{4}{*}{1} & $\bar{Z}$ & 1 & 0 & $(-2 M-5)$ & $(3 \mathrm{M}+3)$ & 0 & 0 & $-6 M+12$ \\
\hline & $\mathrm{X} 1$ & 0 & 1 & 0 & 1 & 0 & 0 & 4 \\
\hline & $\mathrm{S}_{2}$ & 0 & 0 & 2 & 0 & 1 & 0 & 12 \\
\hline & $\mathrm{R}_{3}$ & 0 & 0 & 2 & -3 & 0 & 1 & 6 \\
\hline \multirow{4}{*}{2} & $\bar{Z}$ & 1 & 0 & 0 & $-9 / 2$ & 0 & $(\mathrm{M}+5 / 2)$ & 27 \\
\hline & $\mathrm{X} 1$ & 0 & 1 & 0 & 1 & 0 & 0 & 4 \\
\hline & $\mathrm{S}_{2}$ & 0 & 0 & 0 & 3 & 1 & -1 & 6 \\
\hline & $\mathrm{x} 2$ & 0 & 0 & 1 & $-3 / 2$ & 0 & $1 / 2$ & 3 \\
\hline \multirow{4}{*}{3} & $\mathrm{z}$ & 1 & 0 & 0 & 0 & $3 / 2$ & $(\mathrm{M}+1)$ & 36 \\
\hline & $\mathrm{X} 1$ & 0 & 1 & 0 & 0 & $-1 / 3$ & $1 / 3$ & 2 \\
\hline & $\mathrm{S}_{1}$ & 0 & 0 & 0 & 1 & $1 / 3$ & $-1 / 3$ & 2 \\
\hline & $\mathrm{X} 2$ & 0 & 0 & 1 & 0 & $1 / 2$ & 0 & 6 \\
\hline
\end{tabular}

\section{b. Teknik Dua Fase}

Dengan digunakannya konstanta $\mathrm{M}$ yang merupakan bilangan positif yang sangat besar sebagai penalty, maka bisa terjadi kesalahan perhitungan, terutama apabila perhitungan itu dilakukan dengan menggunakan komputer. Kesalahan itu bisa terjadi karena koefisien fungsi tujuan relatif sangat kecil dibandingkan dengan harga $\mathrm{M}$, sehingga komputer akan memperlakukannya sebagai koefisien yang berharga nol. Sebagai contoh, apabila pada persoalan teknik M di atas ditetapkan harga $\mathrm{M}=100.000$, maka koefisien x1 dan x2 pada fungsi tujuannya menjadi $(300.000-3)$ dan $(400.000-5)$.

Kesulitan ini bisa dikurangi dengan menggunakan teknik dua fase. Di sini konstanta $\mathrm{M}$ dihilangkan dengan cara menyelesaikan persoalan dalam dua fase (dua tingkatan) sebagai berikut:

Fase 1:

Fase ini digunakan untuk menguji apakah persoalan yang kita hadapi memiliki solusi fisibel atau tidak. Pada fase ini fungsi tujuan semula diganti dengan meminimumkan jumlah variabel artifisialnya. Jika nilai minimum fungsi tujuan 
baru ini berharga nol (artinya seluruh variabel artifisial berharga nol), berarti persoalan memiliki solusi fisibel, lanjutkan ke fase 2. Tetapi jika nilai minimum fungsi tujuan baru ini berharga positif, maka persoalan tidak memiliki solusi fisibel. STOP.

\section{Fase 2:}

Gunakan solusi basis optimum dari fase 1 sebagai solusi awal bagi persoalan semula. Dalam hal ini ubahlah bentuk fungsi tujuan fase 1 dengan mengembalikannya pada fungsi tujuan persoalan semula. Pemecahan persoalan dilakukan dengan cara seperti biasa.

\section{Contoh:}

Maksimumkan: $\mathrm{z}=3 \mathrm{x} 1+5 \mathrm{x} 2$

Berdasarkan pembatas:

$$
\begin{aligned}
& \mathrm{X} 1 \leq 4 \\
& 2 \mathrm{x}^{2} \leq 12 \\
& 3 \mathrm{x}_{1}+2 \mathrm{x}_{2}=18 \\
& \mathrm{x} 1, \mathrm{x} 2 \geq 0
\end{aligned}
$$

Bentuk standar:

Maksimumkan: $\mathrm{z}=3 \mathrm{x}_{1}+5 \mathrm{x}_{2}+\mathrm{OS}_{1}+\mathrm{OS}_{2}-\mathrm{MR}_{3}$

$$
\begin{aligned}
\mathrm{x} 1_{1}+\mathrm{S}_{1}+\mathrm{S}_{2} & =4 \\
2 \mathrm{x}_{2}+\mathrm{R}_{3}+2 \mathrm{x}_{2} & =18 \\
\mathrm{x}_{1}, \mathrm{x}_{2}, \mathrm{~S}_{1}, \mathrm{~S}_{2}, \mathrm{R}_{3} \geq 0 &
\end{aligned}
$$

Dari persamaan di atas diperoleh harga $\mathrm{R}_{3}=18-3 \mathrm{x}_{1}-2 \mathrm{x}_{2}$

\section{Fase 1:}

Minimumkan: $r=R_{3}$ atau $r=18-3 x_{1}-2 x_{2}$

Berdasarkan pembatas:

$$
\begin{aligned}
\mathrm{x} 1+\mathrm{S}_{1} & =4 \\
3 \mathrm{x} 1+\mathrm{S}_{2}+2 \mathrm{x}_{2}+\mathrm{R}_{3} & =18 \\
\mathrm{x}_{1}, \mathrm{x} 2, \mathrm{~S}_{1}, \mathrm{~S}_{2}, \mathrm{R}_{3} \geq 0 &
\end{aligned}
$$


Tabel 2. Tabel penyelesaian persoalan dengan pembatas ketiga bertanda $=$ menggunakan teknik dua fase (Fase 1)

\begin{tabular}{|c|c|c|c|c|c|c|c|}
\hline Iterasi & Basis & $\mathrm{X} 1$ & $\mathrm{x} 2$ & $\mathrm{~S}_{1}$ & $\mathrm{~S}_{2}$ & $\mathrm{R}_{3}$ & Solusi \\
\hline \multirow{4}{*}{0} & $\mathrm{r}$ & 3 & 2 & 0 & 0 & 0 & 18 \\
\hline & $S_{1}$ & 1 & 0 & 1 & 0 & 0 & 4 \\
\hline & $\mathrm{S}_{2}$ & 0 & 2 & 0 & 1 & 0 & 12 \\
\hline & $\mathrm{R}_{3}$ & 3 & 2 & 0 & 0 & 1 & 18 \\
\hline \multirow{4}{*}{1} & $r$ & 0 & 2 & -3 & 0 & 0 & 6 \\
\hline & $\mathrm{X} 1$ & 1 & 0 & 1 & 0 & 0 & 4 \\
\hline & $\mathrm{S}_{2}$ & 0 & 2 & 0 & 1 & 0 & 12 \\
\hline & $\mathrm{R}_{3}$ & 0 & 2 & -3 & 0 & 1 & 6 \\
\hline \multirow{4}{*}{2} & $\mathrm{r}$ & 0 & 0 & 0 & 0 & -1 & 0 \\
\hline & $\mathrm{X} 1$ & 1 & 0 & 1 & 0 & 0 & 4 \\
\hline & $\mathrm{S}_{2}$ & 0 & 0 & 3 & 1 & -1 & 6 \\
\hline & $\mathrm{x} 2$ & 0 & 1 & $-3 / 2$ & 0 & $1 / 2$ & 3 \\
\hline
\end{tabular}

Persoalan di atas memiliki solusi fisibel. Selanjutnya R tidak diikutsertakan lagi.

Fase 2:

Dari tabel optimum pada fase 1 di atas dapat dituliskan persamaan-persamaan berikut:

$$
\begin{aligned}
\mathrm{x}_{1}+\underset{3 \mathrm{~S}_{1}+\mathrm{S}_{2}=6}{\mathrm{~S}_{1}=4} & \rightarrow_{\mathrm{x} 1=4-\mathrm{S}_{1}} \\
\mathrm{x} 2_{2}-3 / 2 \mathrm{~S}_{1}=3 & \rightarrow \mathrm{x}_{2}=3+3 / 2 \mathrm{~S}_{1}
\end{aligned}
$$

Kembali kepada model persoalan semula, dan dengan menyubstitusikan persamaan-persamaan di atas, kita dapatkan:

Maksimumkan: $\mathrm{z}=3\left(4-\mathrm{S}_{1}\right)+5\left(3-3 / 2 \mathrm{~S}_{1}\right)$

$$
\text { atau } \mathrm{z}=9 / 2 \mathrm{~S}_{1}+27
$$

Berdasarkan pembatas:

$$
\begin{aligned}
\mathrm{X}_{1}+\mathrm{S}_{1} & =4 \\
3 \mathrm{~S}_{1}+\mathrm{S}_{2} & =6 \\
\mathrm{x}_{2}-3 / 2 \mathrm{~S}_{1} & =3
\end{aligned}
$$


Tabel 3. Tabel penyelesaian persoalan dengan pembatas ketiga bertanda $=$ menggunakan teknik dua fase (Fase 2)

\begin{tabular}{|c|c|c|c|c|c|c|}
\hline Iterasi & Basis & $\mathrm{X} 1$ & $\mathrm{x} 2$ & $\mathrm{~S}_{1}$ & $\mathrm{~S}_{2}$ & Solusi \\
\hline \multirow{4}{*}{0} & $\mathrm{Z}$ & 0 & 0 & $-9 / 2$ & 0 & 27 \\
\hline & $\mathrm{X} 1$ & 1 & 0 & 1 & 0 & 4 \\
\hline & $\mathrm{S}_{2}$ & 0 & 0 & 3 & 1 & 6 \\
\hline & $\mathrm{x} 2$ & 0 & 1 & $-3 / 2$ & 0 & 3 \\
\hline \multirow{4}{*}{1} & $\mathrm{Z}$ & 0 & 0 & $\overline{0}$ & $3 / 2$ & 36 \\
\hline & $\mathrm{X} 1$ & 1 & 0 & 0 & $-1 / 3$ & 2 \\
\hline & $\mathrm{S}_{1}$ & 0 & 0 & 1 & $1 / 3$ & 2 \\
\hline & $\mathrm{X} 2$ & 0 & 1 & 0 & $1 / 2$ & 6 \\
\hline
\end{tabular}

Didapat solusi optimal: $\mathrm{x} 1=2, \mathrm{x} 2=6$, dengan $\mathrm{z}=36$.

\section{METODOLOGI PEMECAHAN MASALAH}

Bahan baku yang digunakan di sebuah industri meubel adalah kayu, begitu juga dengan industri meubel Cipta Karya Mandiri ini yang menjadi obyek penelitian. Biasanya, industri meubel ini menggunakan kayu batangan yang masih berbentuk lonjoran dengan panjang sekitar 2 atau 4 meter per lonjornya, tergantung jenis produk yang akan dibuatnya. Kayu lonjoran tersebut kemudian dipotong-potong menurut kebutuhan sesuai dengan dimensi komponen-komponen produk yang akan dibuat.

Penelitian ini difokuskan pada produk meja, khususnya meja murid yang dipesan oleh SDN 04 Adiarsa Timur Karawang. Meskipun demikian, tema dari penelitian ini bisa juga diterapkan untuk produk-produk meubel yang lain, seperti kursi, lemari, dan lain-lain. Pada dasarnya, tidak ada pertimbangan khusus mengapa peneliti mengambil fokus penelitian pada produk meja ini. Untuk membuat meja, perusahaan meubel Cipta Karya Mandiri menggunakan bahan berupa kayu batangan dengan panjang 2 meter per lonjor atau per batangnya. Dalam kaitannya dengan pembuatan produk meja ini, maka kayu lonjoran sepanjang 2meter yang menjadi bahan baku tersebut dipotong-potong sepanjang yang dibutuhkan untuk komponenkomponen kaki meja, alas meja, dan sebagainya.

Selama ini, pemotongan kayu lonjoran menjadi ukuran-ukuran tertentu sesuai dengan kebutuhan terkesan asal-asalan atau seadanya tanpa perhitungan tentang bagaimana sebaiknya pemotongan tersebut dilakukan agar sisa bahan yang terbuang dapat ditekan hingga sesedikit mungkin. Hal inilah yang menjadi dasar pemikiran dilakukannya penelitian ini. 
Metode pemecahan masalah yang digunakan dalam penelitian ini adalah metode programa linier (linear programming), dimana hasil akhir pemecahan masalah dicari dengan menggunakan metode simpleks dengan Teknik Dua Fase.

Instrumen penelitian yang digunakan untuk mengumpulkan data yang diperlukan dalam penelitian ini berupa lembar observasi atau lembar pengamatan. Lembar observasi ini berisi mengenai data-data ukuran bahan kayu yang digunakan untuk komponen-komponen meja. Bentuk lembar observasi untuk penelitian ini dapat dilihat pada halaman berikut.

Mengingat komponen-komponen pembentuk meja di atas ada 6 (enam) dan menggunakan bahan yang berbeda dengan dimensi yang berbeda-beda pula, maka Penulis membatasi fokus pemecahan masalah hanya pada komponen-komponen yang menggunakan bahan yang sama dan memiliki sedikitnya 2 (dua) jenis dimensi dengan ukuran yang sama. Berdasarkan lembar observasi tersebut, komponen-komponen yang memiliki 2 (dua) dimensi dengan ukuran yang sama adalah kaki meja, pijakan kaki, dan penahan kaki meja.

\section{Tabel 4. Lembar Observasi Penelitian}

Nama Obyek : Meja Murid

Pemesan : SDN 04 Adiarsa Timur, Karawang

Jumlah Pesanan : 200 (dua ratus) unit

\begin{tabular}{|c|c|c|c|c|c|c|c|}
\hline \multirow[b]{2}{*}{ No } & \multirow[b]{2}{*}{$\begin{array}{c}\text { Komponen } \\
\text { yang diamati }\end{array}$} & \multirow{2}{*}{$\begin{array}{c}\text { Bahan } \\
\text { yang } \\
\text { digunakan }\end{array}$} & \multicolumn{3}{|c|}{ Dimensi Komponen } & \multirow{2}{*}{$\begin{array}{c}\text { Banyaknya } \\
\text { komponen yang } \\
\text { diperlukan per } \\
\text { meja (unit) }\end{array}$} & \multirow[b]{2}{*}{ Keterangan } \\
\hline & & & $\begin{array}{c}\mathrm{P} \\
(\mathrm{cm})\end{array}$ & $\begin{array}{c}\mathrm{L} \\
(\mathrm{cm})\end{array}$ & $\begin{array}{c}\mathrm{T} \\
(\mathrm{cm})\end{array}$ & & \\
\hline 1 & Alas Meja & Papan & 120 & 80 & 2 & 1 & \\
\hline 2 & Kaki Meja & Balok & 4 & 3 & 76 & 4 & \\
\hline 3 & Pijakan Kaki & Balok & 110 & 4 & 3 & 1 & \\
\hline 4 & Lis Panjang & Balok & 110 & 2 & 10 & 2 & \\
\hline 5 & Lis Pendek & Balok & 70 & 2 & 10 & 2 & \\
\hline 6 & $\begin{array}{l}\text { Penahan } \\
\text { kaki meja }\end{array}$ & Balok & 70 & 3 & 4 & 2 & \\
\hline
\end{tabular}

Catatan: $\mathrm{P}=$ panjang; $\mathrm{L}=$ lebar; $\mathrm{T}=$ tinggi 


\section{HASIL DAN PEMBAHASAN}

Industri meubel Karya Cipta Mandiri mendapatkan pesanan dari SDN 04 Adiarsa Timur, Karawang untuk membuat meja murid sebanyak 200 (dua ratus) unit dengan spesifikasi sebagaimana terlihat dalam instrumen penelitian di atas.

Sebagaimana yang telah disebutkan pada bagian metodologi pemecahan masalah di atas, bahwa pembahasan masalah dalam penelitian ini adalah mengenai pemotongan bahan kayu yang digunakan pihak perusahaan untuk membuat produknya, maka kita bisa memanfaatkan metode operations research (Penelitian operasional), yaitu dengan menggunakan model programa linier (linear programming) yang dipecahkan dengan teknik simpleks.

Adapun langkah-langkah pemecahan masalah di atas dengan metode simpleks adalah sebagai berikut:

\section{Menghitung kebutuhan total untuk masing-masing komponen}

Dalam penelitian ini, komponen meja yang menjadi fokus pembahasan adalah komponen yang memiliki sedikitnya 2 (dua) dimensi dengan ukuran yang sama, dalam hal ini adalah kaki meja, pijakan kaki, dan penahan kaki meja (ketiganya memiliki lebar dan tinggi yang sama yaitu $3 \mathrm{~cm} \mathrm{x} 4 \mathrm{~cm}$ ).

Kebutuhan akan ketiga komponen tersebut guna memenuhi pesanan sebanyak 200 unit meja dalam dilihat dalam tabel berikut:

Tabel 1. Kebutuhan Ketiga Komponen untuk 200 unit Meja

\begin{tabular}{|r|l|c|c|c|}
\hline No & \multicolumn{1}{|c|}{ Nama Komponen } & $\begin{array}{c}\text { Ukuran } \\
\text { Komponen }(\mathrm{cm})\end{array}$ & $\begin{array}{c}\text { Kebutuhan per } \\
\text { meja (unit) }\end{array}$ & $\begin{array}{c}\text { Kebutuhan } \\
\text { Total (unit) }\end{array}$ \\
\hline 1. & Kaki meja & 76 & 4 & $4 \times 200=800$ \\
\hline 2. & Pijakan kaki & 110 & 1 & $1 \times 200=200$ \\
\hline 3. & Penahan kaki meja & 70 & 2 & $2 \times 200=400$ \\
\hline
\end{tabular}

Catatan: ukuran komponen di atas adalah ukuran dimensi komponen yang berbeda, untuk dimensi yang ukurannya sama tidak ditampilkan

Untuk membentuk/membuat ketiga komponen ini digunakan kayu batangan/ lonjoran dengan panjang $2 \mathrm{~m}$ atau $200 \mathrm{~cm}$ per batang.

2. Menentukan teknik-teknik pemotongan yang mungkin dilakukan

Setelah kita mengetahui kebutuhan total dari tiap komponen yang akan dibuat, langkah selanjutnya adalah menentukan teknik-teknik pemotongan yang mungkin dilakukan. Maksudnya adalah bagaimana cara yang kita lakukan untuk memotong kayu lonjoran sepanjang $2 \mathrm{~m}$ menjadi ukuran $76 \mathrm{~cm}, 110 \mathrm{~cm}$, dan $70 \mathrm{~cm}$. 
Untuk keperluan ini, kita bisa menggunakan cara sebagai berikut:

Misalnya kayu lonjoran $2 \mathrm{~m}$ tersebut kita potong-potong menjadi ukuran $76 \mathrm{~cm}$ sebanyak 2 kali yang akan menghasilkan sisa pemotongan dengan panjang $48 \mathrm{~cm}$.

Teknik-teknik pemotongan yang mungkin dilakukan ini secara lengkap ditunjukkan dalam tabel berikut:

Tabel 2. Teknik-teknik Pemotongan yang Mungkin Dilakukan

\begin{tabular}{|c|c|c|c|c|c|}
\hline Teknik & Panjang & \multicolumn{3}{|c|}{ Ukuran Pemotongan $(\mathrm{cm})$} & Sisa Potong \\
\cline { 3 - 4 } Pemotongan & Standar $(\mathrm{cm})$ & 1 & 2 & 3 & \\
\hline 1 & 200 & 70 & 70 & & 60 \\
\hline 2 & 200 & 70 & 76 & & 54 \\
\hline 3 & 200 & 70 & 110 & & 20 \\
\hline 4 & 200 & 76 & 76 & & 48 \\
\hline 5 & 200 & 76 & 110 & & 14 \\
\hline
\end{tabular}

Setelah diperoleh teknik-teknik pemotongan yang mungkin dilakukan, selanjutnya hasil perhitungan tadi dimasukkan ke dalam rekapitulasi sebagai berikut :

Tabel 3. Rekapitulasi Teknik-teknik Pemotongan

\begin{tabular}{|c|c|c|c|c|c|c|}
\hline \multirow{2}{*}{$\begin{array}{l}\text { Panjang yang } \\
\text { Diinginkan }(\mathrm{cm})\end{array}$} & \multicolumn{5}{|c|}{$\begin{array}{l}\text { Jumlah Potongan yang Dihasilkan oleh Teknik } \\
\text { Potong ke- } \\
\end{array}$} & \multirow{2}{*}{$\begin{array}{l}\text { Kebutuhan batang } \\
\text { kayu per ukuran } \\
\text { (unit) }\end{array}$} \\
\hline & 1 & 2 & 3 & 4 & 5 & \\
\hline 70 & 2 & 1 & 1 & 0 & 0 & 400 \\
\hline 76 & 0 & 1 & 0 & 2 & 1 & 800 \\
\hline 110 & 0 & 0 & 1 & 0 & 1 & 200 \\
\hline $\begin{array}{l}\text { Sisa pemotongan } \\
\text { tak terpakai }(\mathrm{cm})\end{array}$ & 60 & 54 & 20 & 48 & 14 & \\
\hline
\end{tabular}

3. Membuat formulasi programa linier

Setelah rekapitulasi teknik pemotongan diperoleh, langkah selanjutnya adalah membuat formulasi programa linier.

Suatu programa linier mengandung komponen-komponen sebagai berikut:

a. Fungsi tujuan

Fungsi tujuan yang diinginkan dalam masalah ini adalah untuk meminimumkan (minimasi) sisa potongan yang terbuang atau mempunyai ukuran tidak sesuai dengan kebutuhan.

b. Variabel

Komponen yang menjadi variabel dalam penelitian ini adalah teknik-teknik pemotongan yang menghasilkan ukuran potongan kayu sesuai kebutuhan. 
Misalnya variabel x1 adalah teknik pemotongan ke-1 yang menghasilkan potongan kayu dengan ukuran $70 \mathrm{~cm}$ sebanyak 2 unit.

c. Pembatas (constraint)

Yang menjadi pembatas (constraint) dalam pemecahan masalah ini adalah jumlah kebutuhan masing-masing ukuran komponen yang akan dibuat.

Berdasarkan tabel 3 dan penjelasan di atas, dapat diketahui bahwa persoalan ini adalah persoalan minimasi (dalam hal ini adalah meminimumkan sisa potong yang terbuang). Dengan demikian, maka formulasi programa linier untuk masalah ini adalah sebagai berikut :

Fungsi tujuan :

Minimumkan $Z=60 \times 1+54 \times 2+20 \times 3+48 \times 4+14 \times 5$

Berdasarkan pembatas :

$$
\begin{aligned}
& 2 \mathrm{x}_{1}+\mathrm{x}_{2}+\mathrm{x}_{3} \geq 400 \\
& \mathrm{x}_{2}+2 \mathrm{x}_{4}+\mathrm{x}_{5} \geq 800 \\
& \mathrm{x}_{3}+\mathrm{x}_{5} \geq 200 \\
& \mathrm{x} 1, \mathrm{x} 2, \mathrm{x} 3, \mathrm{x} 4, \mathrm{x} 5 \geq 0
\end{aligned}
$$

4. Menyelesaikan permasalahan dengan teknik simpleks

Langkah berikutnya dalam pemecahan masalah ini adalah menentukan teknik simpleks yang akan digunakan untuk perhitungan cara pemotongan kayu yang optimal. Bila kita perhatikan formulasi programa linier di atas, terlihat bahwa persoalan pemotongan kayu ini mempunyai pembatas yang bertanda $\geq$ (sama dengan atau lebih besar dari). Untuk memecahkan masalah dengan pembatas bertanda $\geq$, Tjutju Tarliah Dimyati dan Ahmad Dimyati dalam bukunya (1999 : 64 -74) menyarankan untuk menggunakan metode simpleks dengan Teknik Dua Fase, dimana dalam penyelesaian persoalannya dilakukan dalam dua fase.

Cara pemecahan masalah dengan teknik dua fase ini adalah sebagai berikut:

a. Mengubah bentuk formulasi programa linier sebelumnya ke dalam bentuk kanonik

Bentuk kanonik dari formulasi programa linier di atas adalah :

$$
\begin{array}{ll}
\text { Minimumkan } & \mathrm{Z}=60 \mathrm{x}_{1}+54 \mathrm{x}_{2}+20 \mathrm{x}_{3}+48 \mathrm{x}_{4}+14 \mathrm{x}_{5}+\mathrm{OS}_{1}+\mathrm{OS}_{2}+\mathrm{OS}_{3}+ \\
& \mathrm{MR}_{1}+\mathrm{MR}_{2}+\mathrm{MR}_{3}
\end{array}
$$


atau

Minimumkan $Z-60 x_{1}-54 x_{2}-20 x_{3}-48 x_{4}-14 x_{5}-O_{1}-O_{2}-O_{3}-M_{1}-$

$$
\mathrm{MR}_{2}-\mathrm{MR}_{3}=0
$$

Berdasarkan pembatas :

$$
\begin{aligned}
& 2 x_{1}+x_{2}+x_{3}-S_{1}+R_{1}=400 \\
& x_{2}+2 x_{4}+x_{5}-S_{2}+R_{2}=800 \\
& x_{3}+x_{5}-S_{3}+R_{3}=200 \\
& x_{1}, x_{2}, x_{3}, x_{4}, x_{5}, S_{1}, S_{2}, S_{3}, R_{1}, R_{2}, R_{3} \geq 0
\end{aligned}
$$

b. Melakukan perhitungan untuk fase ke-1

Dari persamaan pembatas di atas diperoleh persamaan-persamaan berikut:

$$
\begin{aligned}
& \mathrm{R}_{1}=400-2 \mathrm{x}_{1}-\mathrm{x}_{2}-\mathrm{x}_{3}+\mathrm{S}_{1} \\
& \mathrm{R}_{2}=800-\mathrm{x}_{2}-2 \mathrm{x}_{4}-\mathrm{x}_{5}+\mathrm{S}_{2} \\
& \mathrm{R}_{3}=200-\mathrm{x} 3-\mathrm{x} 5+\mathrm{S}_{3}
\end{aligned}
$$

\section{Fase 1:}

Fungsi tujuan untuk fase ke-1 menjadi:

Minimumkan: $r=R_{1}+R_{2}+R_{3}$

$\mathrm{r}=400-2 \mathrm{x}_{1}-\mathrm{x}_{2}-\mathrm{x}_{3}+\mathrm{S}_{1}+800-\mathrm{x}_{2}-2 \mathrm{x}_{4}-\mathrm{x}_{5}+\mathrm{S}_{2}+200-\mathrm{x}_{3}-\mathrm{x}_{5}+\mathrm{S}_{3}$

atau $: r=1400-2 x_{1}-2 x_{2}-2 x_{3}-2 x_{4}-2 x_{5}+S_{1}+S_{2}+S_{3}$ Berdasarkan

pembatas :

$$
\begin{aligned}
& 2 x_{1}+x_{2}+x_{3}-S_{1}+R_{1}=400 \\
& x_{2}+2 x_{4}+x_{5}-S_{2}+R_{2}=800 \\
& x_{3}+x_{5}-S_{3}+R_{3}=200 \\
& x_{1}, x_{2}, x_{3}, x_{4}, x_{5} \geq 0
\end{aligned}
$$

Selanjutnya, fungsi tujuan yang baru ini diselesaikan dengan menggunakan metode simpleks, sebagaimana diperlihatkan dalam tabel 4 berikut.

Dari perhitungan dengan teknik simpleks tersebut, diketahui bahwa persoalan ini mempunyai solusi yang fisibel. Persoalan dikatakan mempunyai solusi yang fisibel apabila pada iterasi terakhir, solusi pada ruas kanan bernilai 0 (nol) dimana semua variabel artifisial berharga 0 (nol). Selanjutnya dilakukan perhitungan untuk fase ke-2 tanpa mengikutsertakan variabel artifisial $\mathrm{R}$ dan fungsi tujuan dikembalikan lagi menjadi fungsi tujuan awal. 
Tahel 4. Tahel Sinqleks dg Tekrik 2 Fase urtuk Masalah Pemotongan Batang Kayu (Fase 1)

\begin{tabular}{|c|c|c|c|c|c|c|c|c|c|c|c|c|c|}
\hline Iterasi & BV & $x_{1}$ & $x_{2}$ & $\mathrm{x}_{2}$ & $x_{4}$ & $x_{3}$ & $S_{1}$ & $S_{2}$ & $S_{2}$ & $R_{1}$ & $\mathbb{R}_{2}$ & $\mathbf{R}_{2}$ & Solusi \\
\hline \multirow{4}{*}{0} & $x$ & 2 & 2 & 2 & 2 & 2 & -1 & -1 & -1 & 0 & 0 & 0 & 1400 \\
\hline & $R_{1}$ & 2 & 1 & 1 & 0 & 0 & -1 & 0 & 0 & 1 & 0 & 0 & 400 \\
\hline & $\mathrm{R}_{2}$ & 0 & 1 & 0 & 2 & 1 & 0 & -1 & 0 & 0 & 1 & 0 & 800 \\
\hline & $\mathrm{R}_{2}$ & 0 & 0 & 1 & 0 & 1 & 0 & 0 & -1 & 0 & 0 & 1 & 200 \\
\hline \multirow{4}{*}{1} & $x$ & 0 & 1 & 1 & 2 & 2 & 0 & -1 & -1 & -1 & 0 & 0 & 1000 \\
\hline & $x_{1}$ & 1 & 0.5 & 0.5 & 0 & 0 & .0 .5 & 0 & 0 & 0.5 & 0 & 0 & 200 \\
\hline & $\mathrm{R}_{2}$ & 0 & 1 & 0 & 2 & 1 & 0 & -1 & 0 & 0 & 1 & 0 & 800 \\
\hline & $\mathrm{R}_{2}$ & 0 & 0 & 1 & 0 & 1 & 0 & 0 & -1 & 0 & 0 & 1 & 200 \\
\hline \multirow{4}{*}{2} & $x$ & 0 & 0 & 1 & 0 & 1 & 0 & 0 & -1 & -1 & -1 & 0 & 200 \\
\hline & $x_{1}$ & 1 & 0.5 & 0.5 & 0 & 0 & .0 .5 & 0 & 0 & 0.5 & 0 & 0 & 200 \\
\hline & $x_{4}$ & 0 & 1 & 0 & 1 & 1 & 0 & -1 & 0 & 0 & 1 & 0 & 400 \\
\hline & $\mathrm{R}_{\mathrm{j}}$ & 0 & 0 & 1 & 0 & 1 & 0 & 0 & -1 & 0 & 0 & 1 & 200 \\
\hline \multirow{4}{*}{3} & $y$ & 0 & 0 & 0 & 0 & 1 & 0 & 0 & -1 & -1 & -1 & 0 & 200 \\
\hline & $x_{1}$ & 1 & 0.5 & 0 & 0 & -0.5 & -0.5 & 0 & 0.5 & 0.5 & 0 & .0 .5 & 100 \\
\hline & $x_{4}$ & 0 & 0.5 & 0 & 1 & 0.5 & 0 & -0.5 & 0 & 0 & 0.5 & 0 & 400 \\
\hline & $x_{3}$ & 0 & 0 & 1 & 0 & 1 & 0 & 0 & -1 & 0 & 0 & 1 & 200 \\
\hline \multicolumn{8}{|c|}{ Melakukan perhitungan untuk fase ke-2 } & $\overline{0}$ & 0 & -1 & -1 & -1 & 0 \\
\hline & $x_{1}$ & 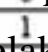 & 0.5 & 0.5 & 0 & 0 & -0.5 & 0 & 0 & 0.5 & 0 & 0 & 200 \\
\hline & $\operatorname{lkg}_{4} \mathrm{n}$ & ig. & (ans & erby & ngan & ase & $2-2$ iा & 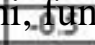 & gsitsu & juan & $\arg s$ & dikem & balikgan \\
\hline & $x_{3}$ & 0 & 0 & 1 & 0 & 1 & 0 & 0 & -1 & 0 & 0 & 1 & 200 \\
\hline
\end{tabular}

menjadi fungsi tujuan awal, sedangkan pembatasnya diperoleh berdasarkan hasil iterasi terakhir dari fase 1 di atas, yaitu sebagai berikut:

Minimumkan $\mathrm{z}=60 \mathrm{x}_{1}+54 \mathrm{x}_{2}+20 \mathrm{x}_{3}+48 \mathrm{x}_{4}+14 \mathrm{x}_{5}+\mathrm{S}_{1}+\mathrm{S}_{2}+\mathrm{S}_{3}$ atau Minimumkan: $\mathrm{z}-60 \mathrm{x}_{1}-54 \mathrm{x}_{2}-20 \mathrm{x}_{3}-48 \mathrm{x}_{4}-14 \mathrm{x}_{5}-\mathrm{S}_{1}-\mathrm{S}_{2}-\mathrm{S}_{3}$

Berdasarkan pembatas :

$$
\begin{aligned}
& x_{1}+0,5 x_{2}+0,5 x_{3}-0,5 S_{1}=200 \\
& 0,5 x_{2}-0,5 x_{3}+x_{4}-0,5 S_{2}=300 \\
& x_{3}+x_{5}-S_{3}=200 \\
& x_{1}, x_{2}, x_{3}, x_{4}, x_{5} \geq 0
\end{aligned}
$$

Dengan menggunakan hasil tabel simpleks iterasi terakhir (keempat) pada fase ke-1 di atas (Tabel 4), diperoleh tabel simpleks untuk fase ke-2 sebagaimana dapat dilihat dalam tabel 5 di bawah ini. 
Tabel 5. Tabel Simpleks dg Teknik 2 Fase untuk Masalah Pemotongan Batang Kayu (Fase 2)

\begin{tabular}{|c|c|c|c|c|c|c|c|c|c|c|}
\hline Iterasi & $\mathrm{BV}$ & $\mathrm{x}_{1}$ & $\mathrm{x}_{2}$ & $\mathrm{x}_{3}$ & $\mathrm{x}_{4}$ & $\mathrm{x}_{5}$ & $\mathrm{~S}_{1}$ & $\mathrm{~S}_{2}$ & $\mathrm{~S}_{3}$ & Solusi \\
\hline \multirow{4}{*}{0} & $\mathrm{z}$ & 0 & 0 & -1 & 0 & 0 & 0 & 0 & 0 & 0 \\
\cline { 2 - 12 } & $\mathrm{x} 1$ & 1 & 0.5 & 0.5 & 0 & 0 & -0.5 & 0 & 0 & 200 \\
\cline { 2 - 11 } & $\mathrm{x} 4$ & 0 & 0.5 & -0.5 & 1 & 0 & 0 & -0.5 & 0.5 & 300 \\
\cline { 2 - 11 } & $\mathrm{x} 5$ & 0 & 0 & 1 & 0 & 1 & 0 & 0 & -1 & 200 \\
\hline
\end{tabular}

Tabel 5 di atas merupakan tabel optimum. Tabel simpleks untuk persoalan minimasi dinyatakan sebagai tabel optimum apabila pada baris 0 (nol) seluruh koefisien dari semua variabel yang ada bernilai nonpositif (bisa bernilai negatif atau $0(\mathrm{nol}))$.

\section{E. ANALISA HASIL PENGOLAHAN DATA}

Berdasarkan hasil pengolahan data di atas, diberikan beberapa analisa berikut :

1. Dari tabel simpleks fase ke-2 di atas, diperoleh hasil sebagai berikut

$$
\begin{aligned}
& : \mathrm{x}_{1}=200 \\
& \mathrm{x}_{4}=300 \\
& \mathrm{x}_{5}=200
\end{aligned}
$$

Hasil perhitungan di atas dapat diterjemahkan sebagai berikut :

a. $\mathrm{X} 1$ adalah teknik pemotongan ke-1. Jadi, pemotongan yang optimum dapat diperoleh apabila kayu lonjoran dipotong dengan menggunakan teknik pemotongan ke-1 sebanyak 200 kali atau membutuhkan kayu lonjoran dengan panjang $2 \mathrm{~m}$ sebanyak 200 batang untuk membuat 200 unit meja.

b. $\mathrm{x} 4$ adalah teknik pemotongan ke-4. Jadi, pemotongan yang optimum dapat diperoleh bila kayu lonjoran dipotong dengan menggunakan teknik pemotongan ke-4 sebanyak 300 kali atau membutuhkan kayu lonjoran dengan panjang $2 \mathrm{~m}$ sebanyak 300 batang untuk membuat 200 unit meja.

c. $\mathrm{x} 5$ adalah teknik pemotongan ke-5. Jadi, pemotongan yang optimum dapat diperoleh apabila kayu lonjoran dipotong dengan menggunakan teknik pemotongan ke-5 sebanyak 200 kali atau membutuhkan kayu lonjoran dengan panjang $2 \mathrm{~m}$ sebanyak 200 batang untuk membuat 200 unit meja.

Sebagai pembuktian, hasil perhitungan dengan teknik simpleks di atas dibandingkan dengan kebutuhan sebenarnya sebagai berikut:

Tabel 6. Perbandingan antara Hasil Simpleks dengan Kebutuhan Sebenarnya 


\begin{tabular}{|c|c|c|c|c|c|c|c|c|c|c|c|}
\hline \multirow{3}{*}{$\begin{array}{c}\text { Ukuran yang } \\
\text { Dibutuhkan } \\
(\mathrm{cm})\end{array}$} & \multicolumn{9}{|c|}{ Teknik Pemotongan ke- } & \multirow{3}{*}{$\begin{array}{c}\text { Total Potongan } \\
\text { (unit) } \\
\Sigma \mathrm{c} \\
\end{array}$} & \multirow{3}{*}{$\begin{array}{c}\text { Jumlah } \\
\text { Kebutuhan per } \\
\text { Ukuran (unit) }\end{array}$} \\
\hline & \multicolumn{3}{|c|}{1} & \multicolumn{3}{|c|}{4} & \multicolumn{3}{|c|}{5} & & \\
\hline & $\mathrm{a}$ & b & $\mathrm{c}$ & $\mathrm{a}$ & b & $\mathrm{c}$ & $\mathrm{a}$ & $\mathrm{b}$ & $\mathrm{c}$ & & \\
\hline 70 & 2 & 200 & 400 & 0 & 300 & 0 & 0 & 200 & 0 & 400 & 400 \\
\hline 76 & 0 & 200 & 0 & 2 & 300 & 600 & 1 & 200 & 200 & 800 & 800 \\
\hline 110 & 0 & 200 & 0 & 0 & 300 & 0 & 1 & 200 & 200 & 200 & 200 \\
\hline & & & & & & & & & & 1400 & 1400 \\
\hline
\end{tabular}

Keterangan :

$\mathrm{a}=$ Jumlah potongan untuk ukuran tertentu yang dihasilkan oleh teknik pemotongan yang bersangkutan (unit)

$\mathrm{b}=$ Jumlah kayu yang harus dipotong untuk teknik pemotongan yang bersangkutan sesuai hasil teknik simpleks (batang)

$\mathrm{c}=$ Jumlah potongan untuk ukuran tertentu yang dihasilkan sesuai dengan teknik simpleks (= a x b) (unit)

Dari tabel di atas, dapat diketahui bahwa hasil perhitungan dengan teknik simpleks sesuai dengan kebutuhan sebenarnya.

2. Dengan demikian, sesuai dengan tabel 6 di atas, banyaknya kayu batangan (lonjoran) standar yang harus disediakan untuk membuat komponen kaki meja, pijakan kaki, dan penahan kaki meja guna memenuhi pesanan meja murid sebanyak 200 unit adalah :

- Teknik pemotongan ke-1 : 200 batang

- Teknik pemotongan ke-4 : 300 batang

- Teknik pemotongan ke-5 : 200 batang

Sehingga, total kayu yang harus disediakan adalah $200+300+200=700$ batang

\section{F. KESIMPULAN}

Dari hasil pembahasan masalah dan analisis pengolahan data di atas, dapat diambil beberapa kesimpulan sebagai berikut :

1. Untuk mengoptimalkan penggunaan bahan di industri meubel, penentuan pemotongan kayu dapat dilakukan dengan memanfaatkan salah satu model dari metode Operations Research, yaitu model programa linier, yang dipecahkan dengan metode simpleks teknik 2 fase.

2. Dengan menggunakan metode simpleks teknik 2 fase, diketahui ada 3 cara pemotongan yang dapat dilakukan sesuai permasalahan yang dihadapi, yaitu: 
a. Kayu dipotong sepanjang 70cm sebanyak 2 (dua) kali. Cara ini membutuhkan kayu batangan (lonjoran) sebanyak 200 batang

b. Kayu dipotong sepanjang $76 \mathrm{~cm}$ sebanyak 2 (dua) kali. Cara ini membutuhkan kayu batangan (lonjoran) sebanyak 300 batang

c. Kayu dipotong sepanjang $76 \mathrm{~cm}$ sebanyak 1 (satu) kali dan $110 \mathrm{~cm}$ sebanyak 1 (satu) kali. Cara ini membutuhkan kayu lonjoran sebanyak 200 batang

3. Jumlah total kayu kayu batangan (lonjoran) yang dibutuhkan untuk membuat pesanan 200 unit meja murid dari SDN 04 Adiarsa Timur, Karawang, adalah sebanyak 700 batang

\section{G. DAFTAR PUSTAKA}

1. Brinckloe, WD. 1965. Managerial Operations Research. New York: McGraw-Hill.

2. Dimyati, Tjutju Tarliah dan Ahmad Dimyati. 1999. Operations Research (Modelmodel Pengambilan Keputusan). Bandung : Sinar Baru Algensindo.

3. Hadley, G. 1963. Linear Programming. New York : Addison Wesley Inc. Ltd.

4. Hiller, Frederick S. dan Gerald J. Lieberman. 1990. Pengantar Riset Operasi. Terj., Edisi Kelima, Jlid 1. Jakarta : Penerbit Erlangga.

5. Subagyo, Pangestu, Drs., Drs. Marwan Asri, MBA., dan Dr. T. Hani Handoko, MBA. 2000. Dasar-dasar Operations Research. Edisi 2. Yogyakarta : BPFE.

6. Suseno, Agustian, Ir., MBA. 2000. Penelitian Operasional I (Diktat Kuliah). Karawang : TI - Unsika.

7. Taha, Hamdy A. 1996. Riset Operasi : Suatu Pengantar. Terj., Edisi Kelima, Jilid Kesatu. Jakarta : PT. Binarupa Aksara. 
Jurnal Buana Ilmu

ISSN: $2541-6995$

Vol. 1, No. 1, November 2016 